\title{
CLÍNICA NAS TRINCHEIRAS: SOBRE O ATENDIMENTO CLÍNICO A CRIANÇAS EM UMA FAVELA DO RiO DE JANEIRO
}

\author{
Maria Alice Fortes de Albuquerque Maranhão
}

Esta dissertação visa apresentar um projeto de psicologia clínica realizado numa escola municipal, em uma favela do Rio de Janeiro. É realizada uma análise de como o consumo, o medo, a violência e o enfraquecimento das figuras de autoridade estão relacionados com o aumento da violência, como forma de expressão da infância. É feita uma reflexão sobre quais os agenciamentos que o território da favela produz na subjetividade de seus moradores e do psicólogo que exerce a clínica neste território.

\section{BANCA:}

Junia de Vilhena (Orientadora)

Benilton Carlos Bezerra Junior

Sonia Elisabete Altoé

Data da defesa: 23/01/2009 